\title{
The dar Genes of Pseudomonas chlororaphis PCL1606 Are Crucial for Biocontrol Activity via Production of the Antifungal Compound 2-Hexyl, 5-Propyl Resorcinol
}

\author{
Claudia E. Calderón, Alejandro Pérez-García, Antonio de Vicente, and Francisco M. Cazorla \\ Instituto de Hortofruticultura Subtropical y Mediterránea "La Mayora" (IHSM-UMA-CSIC), Departamento de Microbiología, \\ Facultad de Ciencias, Universidad de Málaga, 29071-Málaga, Spain
}

Submitted 14 January 2013. Accepted 4 February 2013.

To determine the genetic basis by which 2-hexyl, 5-propyl resorcinol (HPR) is produced by the biocontrol rhizobacterium Pseudomonas chlororaphis (formerly known as $P$. fluorescens) PCL1606, the presence and role of dar genes were investigated. To accomplish this aim, the pCGNOV-1 plasmid was isolated from a PCL1606 genomic library and was shown to hybridize to various dar probes by Southern blot. An analysis of the pCGNOV-1 genomic DNA revealed the presence of five open reading frames that were homologous to dar genes and had an organization that resembled the arrangement of previously described $P$. chlororaphis strains. Phylogenetic studies resulted in the clustering of PCL1606 with the $P$. chlororaphis subgroup, which supported the renaming of this strain from $P$. fluorescens to $P$. chlororaphis PCL1606. The construction of insertional mutants for each homologous dar gene in $P$. chlororaphis PCL1606 along with their corresponding complemented derivative strains restored HPR production and confirmed the key role of the $\operatorname{dar} A$ and $\operatorname{dar} B$ genes in HPR production and in the antagonistic phenotype. Finally, biocontrol assays were performed on avocado-Rosellinia and tomatoFusarium test systems using the HPR-defective and -complemented derivative strains generated here and demonstrated the crucial role of the biosynthetic dar genes in the biocontrol phenotype of $P$. chlororaphis PCL1606. This biocontrol phenotype is dependent on the dar genes via their production of the HPR antibiotic. Some of the dar genes not directly involved in the biosynthesis of HPR, such as darS or darR, might contribute to regulatory features of HPR production.

Current address for F. M. Cazorla: Bulevar Louis Pasteur-Campus Universitario de Teatinos 31, 29071 Málaga, Spain

Nucleotide DNA sequence reported are available in the GenBank database under accession number JQ663992 for the genomic sequence of Pseudomonas chlororaphis PCL1606 cloned into pCGNOV-1 containing, among others, the dar genes; and $\mathrm{KC} 117306$ and $\mathrm{KC} 117307$ for the $g y r B$ and rpoD sequences of $P$. chlororaphis PCL1606.

Corresponding author: F. M. Cazorla; Telephone: +34 952137587; Fax: +34 952136645; E-mail: cazorla@uma.es

*The $e$-Xtra logo stands for "electronic extra" and indicates that four supplementary figures and one supplementary table are published online.

(C) 2013 The American Phytopathological Society
Using rhizobacteria to biologically control plant diseases could supplement other classical control measures (Haas and Défago 2005). Among the various rhizobacteria that are available for agricultural biocontrol, those of the Pseudomonas genus have been among the most extensively studied because Pseudomonas spp. are aerobic, gram-negative bacteria that are ubiquitous in agricultural soils and are well adapted to growing in the rhizosphere (Weller 2007). Additionally, rhizospheric Pseudomonas spp. possess many traits that make them well suited as biocontrol and growth-promoting agents, including the production of antimicrobial substances (Lugtenberg and Kamilova 2009). The ability of rhizosphere-associated fluorescent pseudomonads to inhibit the growth of phytopathogenic fungi has generated interest in their use as crop protectants because some Pseudomonas spp. have been shown to produce a diverse array of antifungal compounds, such as antibiotics, hydrolytic enzymes, and siderophores, which interfere with the life cycle of the target fungi (Dowling and O'Gara 1994; Gonzalez-Sánchez et al. 2010; Pliego et al. 2011). In many cases, the production of antifungal compounds by microorganisms has been directly correlated with biocontrol activity, and many antagonistic bacterial strains have been effective in plant bioassays (Haas and Défago 2005; Morrissey et al. 2004; Raaijmakers et al. 2002, 2006).

The classical dual plate assay (Geels and Schippers 1983) is the most often employed to screen and select candidate antagonistic biocontrol agents, and this strategy has resulted in the selection of many Pseudomonas strains as potential biocontrol candidates (Haas and Keel 2003; Pliego et al. 2011; Raaijmakers et al. 2002). The Pseudomonas chlororaphis subsp. aurantiaca (formerly named P. fluorescens) BL915 strain, which was isolated from the cotton rhizosphere, is one model strain that has been selected by fungal antagonism. This strain has been effective in fighting against the Rhizoctonia solani-induced damping-off of cotton and other plants (Hill et al. 1994). An investigation of its antagonistic mechanism has demonstrated that $P$. chlororaphis subsp. aurantiaca BL915 produces various antifungal compounds, including the antibiotic 2-hexyl, 5-propyl resorcinol (HPR). HPR was first isolated from an unidentified Pseudomonas sp. in 1975 and has been reported to possess moderate antifungal and antibacterial properties (Kanda et al. 1975; Kitahara and Kanda 1975). The proposed mode of action of 5-alkylresorcinols in vitro is to induce DNA cleavage in the presence of $\mathrm{O}_{2}$ and $\mathrm{Cu}^{2+}$ at alkaline $\mathrm{pH}$ (Pohanka et al. 2006). The genetic mechanism of HPR production by $P$. chlororaphis subsp. aurantiaca BL915 has already been investigated, and previous studies have shown that the responsible genes are located in a cluster containing three biosynthetic 
genes (darA, darB, and darC) followed by two independent regulatory genes (darS and darR) (Nowak-Thompson et al. 2003).

The avocado (Persea americana) plant is an important tropical and subtropical crop worldwide, and the most important diseases affecting this crop are root rots that are primarily caused by the oomycete Phytophthora cinnamomi and the ascomycete fungus Rosellinia necatrix (Pliego et al. 2009, 2012; Sztejnberg and Madar 1980). Our current research has focused on developing biocontrol rhizobacterial strains that would protect against avocado white root rot that is caused by $R$. necatrix. Multiple screening strategies have been previously used to select potential biocontrol candidates (Pliego et al. 2011). A previous screen for fungal inhibition resulted in the isolation of Pseudomonas fluorescens PCL1606. This bacterium was selected due to both its high antagonistic activity against many soilborne phytopathogenic fungi and its production of the antifungal antibiotic HPR. A previous study using random insertional derivative $\mathrm{Tn} 5$ mutants, in both an S-adenosylmethionine (SAM)-dependent methyltransferase and a glycine cleavage system $\mathrm{T}$, has indicated that HPR production could be correlated to the biocontrol of soilborne fungal diseases (Cazorla et al. 2006). However, little is known about the genetic basis of the production of HPR in $P$. fluorescens PCL1606.

In this study, a sequence analysis of the $\operatorname{dar} B$ gene along with various housekeeping genes has allowed us to rename the biocontrol rhizobacterium PCL1606 strain as P. chlororaphis. We have also detected dar-homologous sequences in $P$. chlororaphis PCL1606 and confirmed the role of each of these dar genes in HPR production, antagonism, and biocontrol by a clean genetic strategy involving mutation and mutant complementation experiments. The previously identified role of HPR production in biocontrol emphasizes the biological importance of the dar genes in establishing the relevant phenotypes of $P$. chlororaphis PCL1606.

\section{RESULTS}

\section{The dar genes are present}

in the genome of $P$. chlororaphis PCL1606.

Polymerase chain reaction (PCR)-amplified DNA products of the expected size were obtained using genomic DNA from P. chlororaphis PCL1606 as a template; DNA that was ex- tracted from $P$. chlororaphis subsp. aurantiaca BL915 was used as a positive control. Sequencing the amplified DNA confirmed that sequences that were homologous to dar genes were present in P. chlororaphis PCL1606.

The PCR-amplified partial darA, darB, and $\operatorname{dar} C$ sequences were then used as labeled probes to screen a library of $P$. chlororaphis PCL1606 DNA that had been inserted into phagemids. An initial screen with the $\operatorname{dar} B$ probe resulted in the selection of two plasmids (pCGOCT-1 and pCGNOV-1) that hybridized. A Southern blot revealed that only the pCGNOV-1 (Table 1) plasmid hybridized with the rest of the dar probes; thus, this plasmid was selected for further analysis. In these experiments, the control strain, $P$. protegens Pf-5 (previously called P. fluorescens Pf-5), did not hybridize with any of the dar probes. Sequencing data revealed the open reading frame (ORF) arrangement of the pCGNOV-1 plasmid (Supplementary Fig. S1), and the obtained sequence of the PCL1606 genomic DNA that was cloned into this plasmid was deposited in the National Center for Biotechnology Information (NCBI) GenBank, accession number JQ663992.

A bioinformatic analysis of the $12,123 \mathrm{bp}$ of genomic DNA that was cloned into pCGNOV-1 revealed that this DNA sequence could have 13 ORF; five ORF ( 8 to 12) share high identity with dar gene sequences that have been previously described among members of the P. chlororaphis subgroup. The highest identity at both the nucleotide (Supplementary Fig. S2) and amino acid (Supplementary Fig. S3) level was found in the $d a r$-containing sequences from strains P. chlororaphis subsp. aurantiaca BL915 (GenBank accession number AY135187), P. chlororaphis subsp. aureofaciens 30-84 (GenBank accession number AHHJ01000007.1), and P. chlororaphis 06 (GenBank accession number AHOT01000006.1). Other Pseudomonas strains such as $P$. mendocina NK-01 (GenBank accession number NC 009439), P. fulva 12-X (GenBank accession number NC_015556), and P. stutzeri DSM 10701 (GenBank accession number CP003725) show approximately $55 \%$ sequence similarity at the amino acid level but not at the nucleotide level. The other sequences showed only $\leq 50 \%$ similarity to $\operatorname{darB}$ at both nucleotide and amino acid levels; these belonged to other gram-negative microorganisms that commonly inhabit soils, such as Azoarcus sp. BH72 (GenBank accession number NC_008702), Leadbetterella byssophila DSM 17132 (NC_014655), and three microorganisms belonging to the Flavobacteriaceae group:

Table 1. Plasmid used in this study

\begin{tabular}{|c|c|c|}
\hline Plasmid & Relevant characteristics $^{\mathrm{a}}$ & Reference or source \\
\hline pBlueSTAR-1 & Derived from $\lambda$ BlueSTAR-1 vector by autosubcloning & Novagen, Darmstad, Germany \\
\hline pCGNOV-1 & $\begin{array}{l}\text { 12,123 bp of genomic DNA from wild-type strain } P \text {. chlororaphis PCL1606 cloned into } \\
\text { pBlueSTAR-1 }\end{array}$ & This study \\
\hline pCR2.1-TOPO & TA cloning vector for PCR products, $\mathrm{Amp}^{\mathrm{r}}, \mathrm{Km}^{\mathrm{r}}$ & Invitrogen, San Diego, CA, U.S.A. \\
\hline $\mathrm{p} \Delta \mathrm{DARA} 576$ & $\begin{array}{l}\text { darA fragment ( } 576 \mathrm{bp}) \text { cloned into pCR2.1-TOPO used for construction of insertional mutant on } \\
\text { darA gene of strain P. chlororaphis PCL1606, } \mathrm{Amp}^{\mathrm{r}}, \mathrm{Km}^{\mathrm{r}}\end{array}$ & This study \\
\hline $\mathrm{p} \Delta \mathrm{DARB} 379$ & $\begin{array}{l}\text { darB fragment }(379 \mathrm{bp}) \text { cloned into } \mathrm{pCR} 2.1-\mathrm{TOPO} \text { used for construction of insertional mutant on } \\
\text { darB gene of strain } P \text {. chlororaphis PCL1606, } \mathrm{Amp}^{\mathrm{r}}, \mathrm{Km}^{\mathrm{r}}\end{array}$ & This study \\
\hline $\mathrm{p} \triangle \mathrm{DARC} 153$ & $\begin{array}{l}\text { darC fragment ( } 153 \mathrm{bp}) \text { cloned into pCR2.1-TOPO used for construction of insertional mutant on } \\
\text { darC gene of strain P. chlororaphis PCL1606, } \mathrm{Amp}^{\mathrm{r}}, \mathrm{Km}^{\mathrm{r}}\end{array}$ & This study \\
\hline $\mathrm{p} \Delta \mathrm{DARS} 351$ & $\begin{array}{l}\text { darS fragment ( } 351 \mathrm{bp}) \text { cloned into pCR2.1-TOPO used for construction of insertional mutant on } \\
\text { darS gene of strain P. chlororaphis PCL1606, } \mathrm{Amp}^{\mathrm{r}}, \mathrm{Km}^{\mathrm{r}}\end{array}$ & This study \\
\hline $\mathrm{p} \Delta \mathrm{DARR} 354$ & $\begin{array}{l}\text { darR fragment ( } 354 \mathrm{bp} \text { ) cloned into pCR2.1-TOPO used for construction of insertional mutant on } \\
\text { darR gene of strain P. chlororaphis PCL1606, } \mathrm{Amp}^{\mathrm{r}}, \mathrm{Km}^{\mathrm{r}}\end{array}$ & This study \\
\hline pGEM-T Easy & $\mathrm{T}$ vector for cloning PCR-amplified fragments & Promega Corp., Madison, WI, U.S.A. \\
\hline pGEM-T-darA & pGEM-T Easy derivative containing darA gene. Amp ${ }^{\mathrm{r}}$ & This study \\
\hline pGEM-T-darB & pGEM-T Easy derivative containing darB gene. Amp ${ }^{r}$ & This study \\
\hline pBBR1MSC-5 & Mobilizable broad host range cloning vector. $\mathrm{Gm}^{\mathrm{r}}$ & Kovach et al. 1995 \\
\hline pCOMA & darA gene cloned into pBBR1MCS-5 used for complementing Mutation on strain $\Delta$ darA, $\mathrm{Gm}^{\mathrm{r}}$ & This study \\
\hline pCOMB & darB gene cloned into pBBR1MCS-5 used for complementing Mutation on strain $\Delta$ darB, $\mathrm{Gm}^{\mathrm{r}}$ & This study \\
\hline
\end{tabular}

${ }^{\text {a }} \mathrm{PCR}=$ polymerase chain reaction; $\mathrm{Amp}^{\mathrm{r}}, \mathrm{Km}^{\mathrm{r}}$, and $\mathrm{Gm}^{\mathrm{r}}=$ ampicillin, kanamycin, and gentamicin resistant, respectively . 
Zobellia galactanivorans (NC_015844), Weeksella virosa DSM 16922 (NC_015144), and Flavobacterium psychrophilum JIP02/ 86 (NC_009613).

An analysis of the dar locus and its flanking ORF demonstrated that the synteny in $P$. chlororaphis subsp. aurantiaca BL915, $P$. chlororaphis subsp. aureofaciens 30-84, and $P$. chlororaphis 06 was almost identical to that in $P$. chlororaphis PCL1606; both displayed high similarity at the amino acid level among the predicted Dar sequences. Other Pseudomonas spp. contained sequences that were similar to DarB; however, a low similarity existed at the amino acid level (55 to 57\%) and no other putative Dar sequences were present (Fig. 1).

An analysis of the putative function of each dar-homologous ORF confirmed those functions that had been previously described in the HPR-producing P. chlororaphis subsp. aurantiaca BL915 strain (Fig. 2). The predicted protein encoded by ORF 10 exhibits high levels of similarity to acyl carrier proteins (ACP) and contains the typical attachment site for phospho-pantetheine; therefore, it was designated as darC. BLAST search results identified the protein encoded by ORF 9 as a homolog of a $\beta$-ketoacyl ACP synthase III that also contains a 3-oxoacyl synthase III domain; this sequence was designated as $\operatorname{darB}$. A search of the NCBI protein database revealed that the protein encoded by ORF 8 has no related domains; however, sequence analysis revealed that it was highly similar to a condensing enzyme for diacyl resorcinol; therefore, it was designated as darA. BLAST searches for the putative proteins encoded by both ORF 11 and 12 suggested that these proteins are members of the AraC/XylS family of transcriptional regulators and have a high identity to DarS and DarR, respectively. Thus, the homologous sequences to those genes were subsequently designated as darS and darR, respectively.

The sequences of the $P$. chlororaphis PCL1606 dar genes were then compared with the recently sequenced genomes of several members of the $P$. chlororaphis subgroup, and the analysis was extended to include homologous sequences from the genomes of various Pseudomonas strains that display antagonism and biocontrol phenotypes, such as Pseudomonas sp. Pf0-1, P. fluorescens SBW25, and P. protegens Pf-5 (Fig. 2). The predicted amino acid sequence identity indicated that the

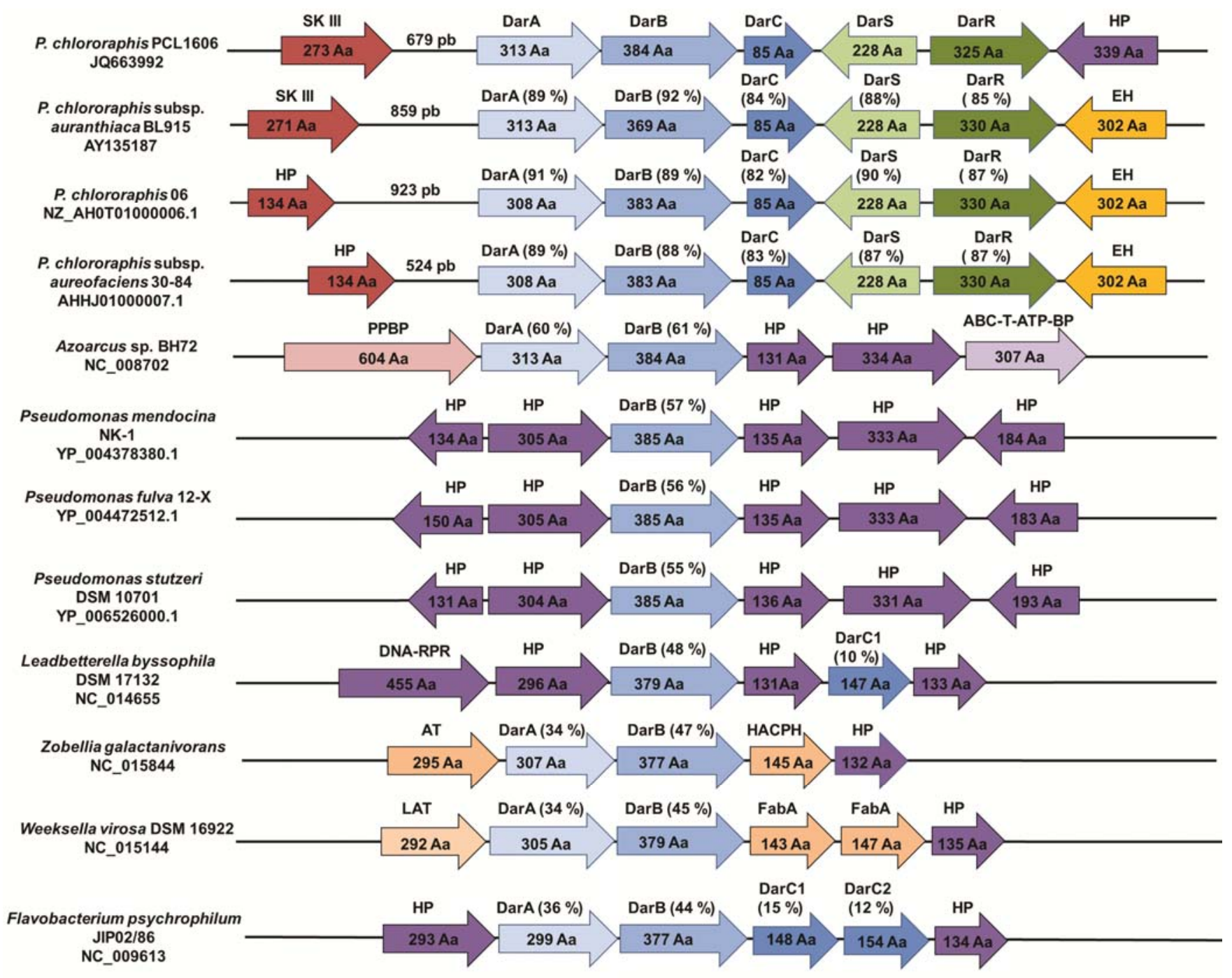

Fig. 1. Comparison of the database-derived DarB homologous sequences at the amino acid level. Each sequence was ranked by its percentage of homology to the darB sequence present in Pseudomonas chlororaphis PCL1606. The same color indicates a similar predicted function for the various open reading frames (ORF). The size (amino acids [aa]) is indicated inside each ORF, the name of the gene is indicated above the corresponding ORF, and the percentage of similarity to the $P$. chlororaphis PCL1606 DarB homologous sequence is indicated in brackets. A predicted function that is different from that of a previously described dar genes is abbreviated as follows: DNA-RPR, DNA repair protein; AT, acetyltransferase; EH, epoxide hydrolase; FABA, $\beta$-hydroxyacyl-(acyl carrier protein) dehydratase FabA/FabZ; HACPH, 3R-hydroximyristoyl-ACP-dehydratase; HP, hypothetical protein; LAT, lipid A biosynthesis acyltransferase; PPBP, putative penicillin-binding protein; SKIII, streptomycin kinase III; ABC-T-ATP-BP, ABC transporter ATP-binding protein. 
darA, darB, and darC genes of PCL1606 were highly homologous (values of 82 to $92 \%$ ) to the dar genes present in the three members of the $P$. chlororaphis subgroup that were analyzed ( $P$. chlororaphis subsp. aurantiaca BL915, $P$. chlororaphis subsp. aureofaciens 30-84, and $P$. chlororaphis 06) but were not present in the genomes of other Pseudomonas biocontrol strains. In contrast, genes with a lesser degree of identity to the $d a r S$ and $d a r R$ genes (73 to $89 \%$ ) were found in the genomes of the sequenced Pseudomonas control strains Pf0-1, SBW25, and Pf-5 (Fig. 2).

Additionally, the phylogenetic relationship among the $P$. chlororaphis PCL1606 strains was further analyzed by comparing a set of two protein-coding housekeeping genes $(\mathrm{gyrB}$ and rpoD) (Fig. 3). The resulting phylogenetic tree showed that PCL1606 grouped together with strains that had been isolated from soil and root environments, strains that were mainly antagonistic against soilborne phytopathogenic fungi, and strains with previously demonstrated biocontrol activity (Fig. 3). These strains all contained DNA sequences that are related to the biosynthesis of antifungal antibiotics, whereas only the $P$. chlororaphis subgroup strains contains all of the biosynthetic sequences for HPR production (Fig. 3). An additional phylogenetic analysis compared all $\operatorname{dar} B$ orthologs that are present in the databases and revealed a close clustering between PCL1606 and the members of the P. chlororaphis subgroup (Supplementary Fig. S4).

\section{Genes $\operatorname{dar} A$ and $\operatorname{dar} B$ are key genes involved in HPR production and the antagonistic activity of $P$. chlororaphis PCL1606.}

Site-directed insertional mutants were constructed to determine the role of the various dar homolog genes in HPR production by $P$. chlororaphis PCL1606, and phenotypic characterization of each derivative mutant ( $\triangle$ darA, $\triangle$ darB, $\Delta$ darC, $\Delta d a r S$, and $\Delta d a r R$ ) was then performed (Table 2). Disrupting darA and $\operatorname{dar} B$ (i.e., derivative strains $\triangle$ darA and $\triangle$ darB) resulted in the failure of HPR production as determined by extraction and thin-layer chromatography (TLC) analysis. The wild-type positive control strain (PCL1606) produced a spot corresponding to HPR along with the $\operatorname{darC}$, darS, and darR derivative mutants (Table 2).

The insertional mutants were next tested for their antagonistic activity against $R$. necatrix $\mathrm{CH} 53$ and Fusarium oxysporum f. sp. radicis-lycopersici ZUM2407 using an agar plate assay. Although the antagonistic activity of $\Delta d a r A$ and $\Delta d a r B$ was markedly reduced, $\Delta d a r C, \triangle d a r S$, and $\triangle d a r R$ retained their antifungal activity and exhibited a phenotype consistent with the wild-type PCL1606 (Table 2).

Finally, to avoid growth problems associated with the mutant insertions that could lead to the failure in HPR production, the growth characteristics of each mutant were evaluated and compared with those of the wild-type strain. Time-course experiments revealed that the growth of the derivative mutants in M9 minimal medium was not significantly affected (data not shown).

The non-HPR-producing derivative $\triangle$ darA and $\Delta$ darB strains were then transformed into the pCOMA and pCOMB plasmids, respectively, and the resulting strains were named ComA and ComB. These constructs were identical to the wildtype strain and were able to restore HPR production and (antifungal) antagonistic activity against $R$. necatrix and $F$. oxysporum (Table 2).

\section{The production of HPR is essential \\ for the biocontrol activity of $P$. chlororaphis PCL1606.}

Biocontrol assays against avocado white root rot and tomato foot and root rot were conducted as previously described by Cazorla and associates (2006). When no bacteria were applied to the avocado roots, the plants infected with $R$. necatrix showed a normalized disease index of $100 \%$ (Fig. 4). However, administering the wild-type $P$. chlororaphis PCL1606 strain reduced the disease index to $60 \%$. The $\Delta d a r C$ and $\Delta d a r S$ derivative strains showed disease indices of 75 and $72 \%$, respectively, which is not statistically different from the control PCL1606 strain. In contrast, the $\triangle d a r A, \Delta d a r B$, and $\Delta d a r R$ insertional mutants showed no significant biocontrol activity in

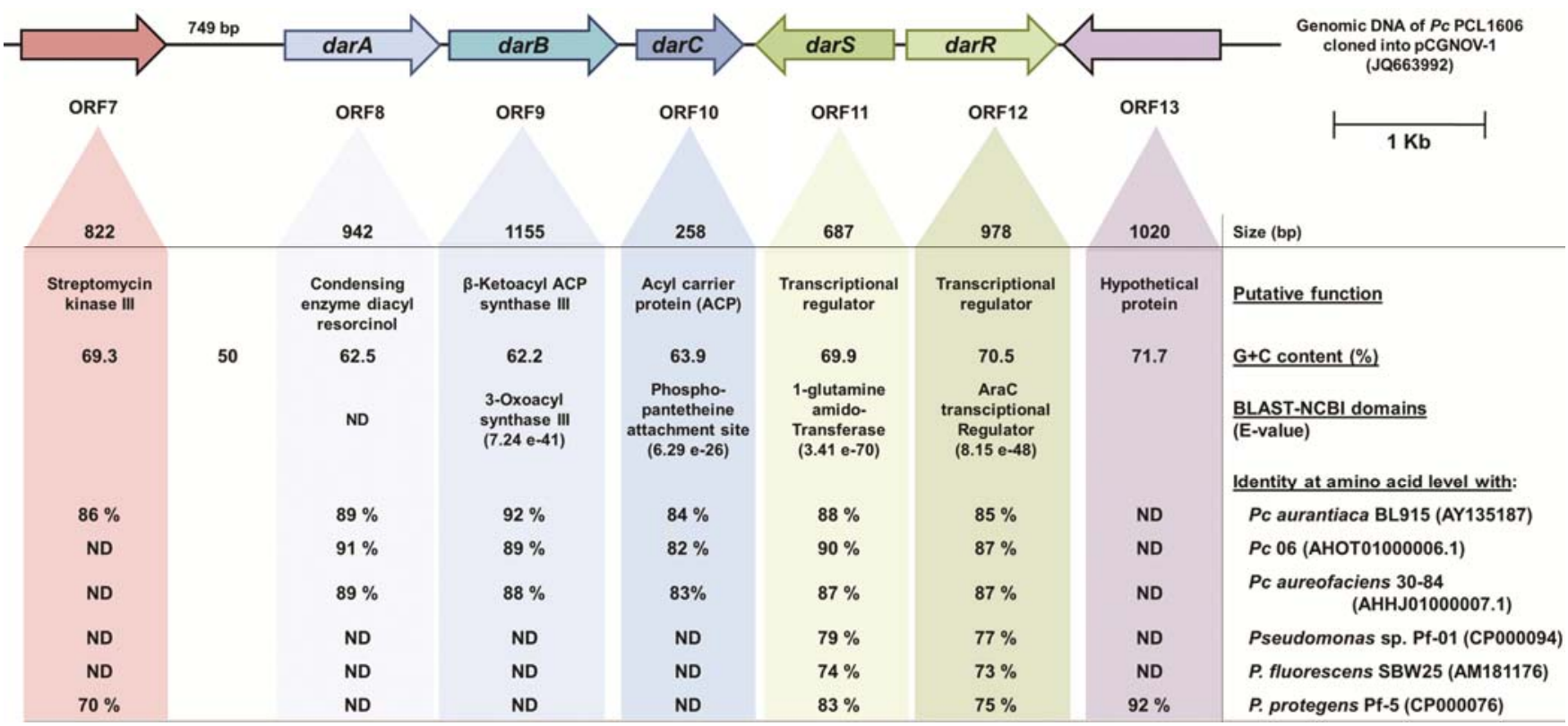

Fig. 2. Homologous open reading frame (ORF) sequences (darABCSR) were identified in the 12,123-bp genomic DNA of Pseudomonas chlororaphis PCL1606 that was cloned into pCGNOV-1. For each ORF, the putative function, $\mathrm{G}+\mathrm{C}$ content, predicted domains (with the corresponding e-value), and identity at the amino acid level with members of the P. chlororaphis subgroup (P. chlororaphis subsp. aurantiaca BL915, P. chlororaphis subsp. aureofaciens 30-84, and P. chlororaphis 06) and other biocontrol Pseudomonas sp. sequences (Pseudomonas sp. Pf0-1, P. fluorescens SBW25, and P. protegens Pf-5) are shown here. 
the avocado- $R$. necatrix test system, with disease indices of 86 to $90 \%$, which is significantly different that the wild-type strain (Fig. 4).

The site-directed mutants were also tested in a tomato-F. oxysporum f. sp. radicis-lycopersici biocontrol system (Fig. 5), and the results were similar to those observed in the avocado$R$. necatrix test system. When no bacteria were added, more than $70 \%$ of the plants showed typical disease symptoms after 21 days of growth in soil that was infested with $F$. oxysporum, whereas the introduction of the wild-type $P$. chlororaphis PCL1606 strain reduced the disease incidence to $33 \%$. None of the insertional dar gene mutants reduced disease symptoms, and the disease index was 72, 60, 52, 47, and 59\% for mutants $\triangle d a r A, \Delta d a r B, \Delta d a r C, \Delta d a r S$, and $\Delta d a r R$, respectively; these values were all significantly different from the value obtained for the wild-type strain (Fig. 5).

The complemented mutants ComA and ComB, in which HPR production is restored after transformation with their corresponding plasmids, also experienced a restoration of their biocontrol activity to levels that were statistically similar to the wild-type PCL1606 strain, which was used as a positive control in both the avocado-R. necatrix (Fig. 4) and tomato-F. oxysporum (Fig. 5) test systems.

\section{DISCUSSION}

The use of heterologous primers allowed various dar sequences to be amplified from $P$. chlororaphis PCL1606. A detailed study of the dar-homologous ORF in the pCGNOV-1

Table 2. Main characteristics of the derivative strains of Pseudomonas chlororaphis PCL1606 used in this study

\begin{tabular}{lccc}
\hline & & \multicolumn{3}{c}{ Antagonism to $^{\mathbf{a}}$} \\
\cline { 3 - 4 } Strain & HPR $^{\mathbf{b}}$ & Rosellinia necatrix & Fusarium oxysporum \\
\hline PCL1606 & + & + & + \\
$\Delta$ darA & - & - & - \\
$\Delta$ darB & - & - & - \\
$\Delta$ darC & + & + & + \\
$\Delta$ darR & + & + & + \\
$\Delta$ darS & + & + & + \\
ComA & + & + & + \\
ComB & + & + & + \\
\hline
\end{tabular}

${ }^{a}$ Bacterial strains showing a mycelial inhibition zone after 5 days of growth were considered antagonistic.

${ }^{b}$ Production of 2-hexyl, 5-propyl resorcinol (HPR). Presence of characteristic spot detected by fractionation of organic extractions on thin-layer chromatography plates.

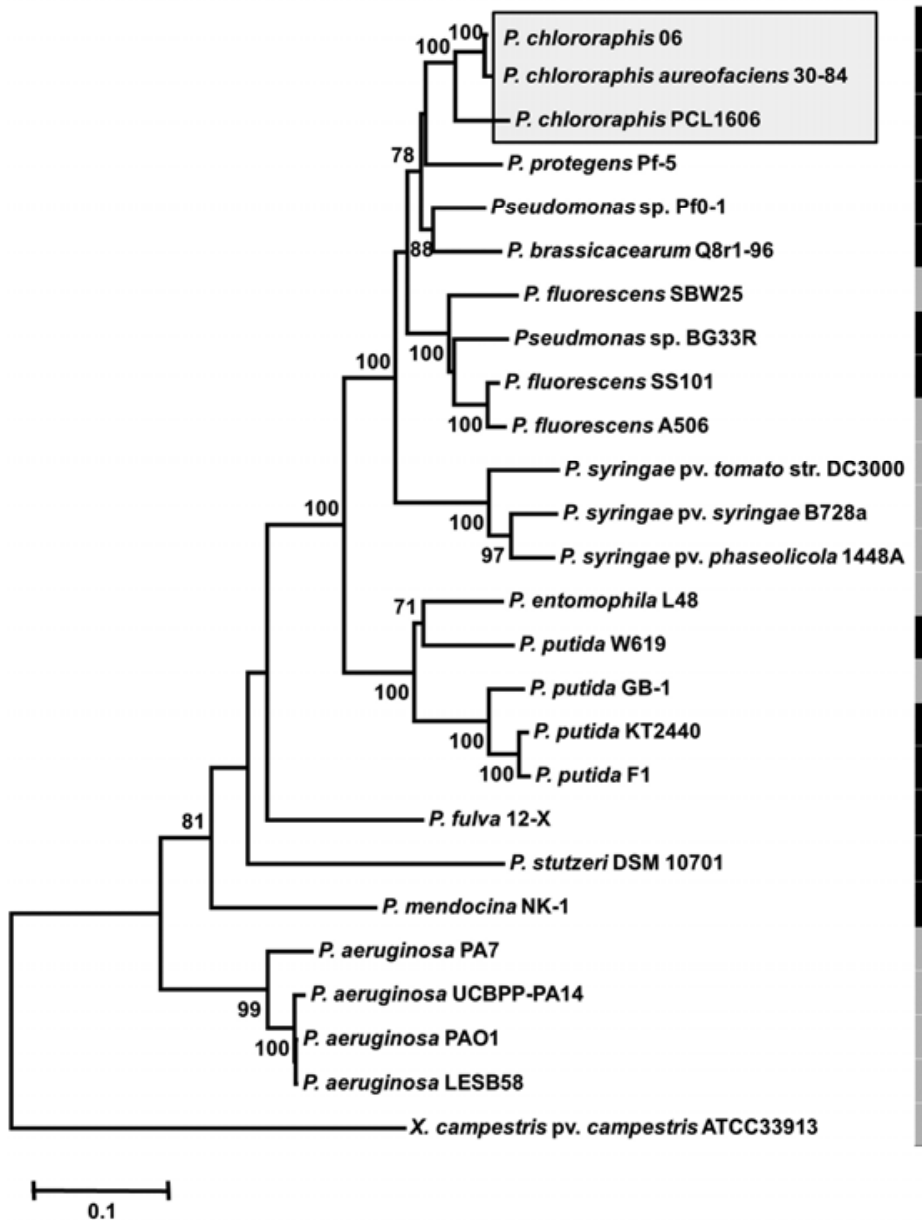

\begin{tabular}{|c|c|c|c|c|c|c|c|c|}
\hline SOURCE & BIOCONTROL & ANTIFUNGAL & & NTIBI & IOTIC & SEQU & ENCE & ES \\
\hline $\mathbf{S}$ & $\mathrm{BC}$ & A & HPR & PRN & PHZ & $\mathrm{HCN}$ & $\mathbf{N}$ & $\mathbf{N}$ \\
\hline $\mathbf{R}$ & $\mathrm{BC}$ & A & HPR & PRN & PHZ & $\mathrm{HCN}$ & $\mathrm{N}$ & $\mathrm{N}$ \\
\hline $\mathbf{R}$ & $\mathrm{BC}$ & A & HPR & NT & NT & $\mathrm{HCN}$ & NT & NT \\
\hline $\mathbf{S}$ & $\mathrm{BC}$ & A & $\mathbf{N}$ & PRN & $\mathbf{N}$ & $\mathrm{HCN}$ & PLT & DAPG \\
\hline $\mathbf{S}$ & BC & A & $\mathbf{N}$ & $\mathbf{N}$ & $\mathbf{N}$ & $\mathrm{HCN}$ & $\mathbf{N}$ & $\mathbf{N}$ \\
\hline $\mathbf{R}$ & BC & A & $\mathbf{N}$ & $\mathbf{N}$ & $\mathbf{N}$ & $\mathrm{HCN}$ & $\mathbf{N}$ & DAPG \\
\hline $\mathbf{F}$ & $\mathrm{BC}$ & NA & $\mathbf{N}$ & $\mathbf{N}$ & $\mathbf{N}$ & $\mathbf{N}$ & $\mathbf{N}$ & $\mathbf{N}$ \\
\hline $\mathbf{R}$ & BC & NA & $\mathbf{N}$ & $\mathbf{N}$ & $\mathbf{N}$ & $\mathbf{N}$ & $\mathbf{N}$ & $\mathbf{N}$ \\
\hline $\mathbf{R}$ & $\mathrm{BC}$ & NA & $\mathbf{N}$ & $\mathbf{N}$ & $\mathbf{N}$ & $\mathbf{N}$ & $\mathbf{N}$ & $\mathbf{N}$ \\
\hline $\mathbf{F}$ & $\mathrm{BC}$ & NA & $\mathbf{N}$ & $\mathbf{N}$ & $\mathbf{N}$ & $\mathbf{N}$ & $\mathbf{N}$ & $\mathbf{N}$ \\
\hline $\mathbf{F}$ & $\mathbf{P}$ & NT & $\mathbf{N}$ & $\mathbf{N}$ & $\mathbf{N}$ & $\mathbf{N}$ & $\mathbf{N}$ & $\mathbf{N}$ \\
\hline $\mathbf{F}$ & $\mathbf{P}$ & NT & $\mathbf{N}$ & $\mathbf{N}$ & $\mathbf{N}$ & $\mathbf{N}$ & $\mathrm{N}$ & $\mathbf{N}$ \\
\hline $\mathbf{F}$ & $\mathbf{P}$ & NT & $\mathbf{N}$ & $\mathbf{N}$ & $\mathrm{N}$ & $\mathrm{N}$ & $\mathrm{N}$ & $\mathbf{N}$ \\
\hline 0 & NT & NT & $\mathbf{N}$ & $\mathbf{N}$ & PHZ & HCN & $\mathrm{N}$ & $\mathbf{N}$ \\
\hline $\mathbf{R}$ & BC & NA & $\mathbf{N}$ & $\mathbf{N}$ & PHZ & $\mathbf{N}$ & $\mathbf{N}$ & $\mathbf{N}$ \\
\hline 0 & NBC & NT & $\mathrm{N}$ & $\mathbf{N}$ & PHZ & $\mathrm{HCN}$ & $\mathrm{N}$ & $\mathbf{N}$ \\
\hline $\mathrm{s}$ & BC & NA & $\mathrm{N}$ & $\mathrm{N}$ & PHZ & $\mathbf{N}$ & $\mathrm{N}$ & $\mathrm{N}$ \\
\hline $\mathbf{S}$ & NBC & NT & $\mathbf{N}$ & $\mathbf{N}$ & PHZ & $\mathbf{N}$ & $\mathbf{N}$ & $\mathbf{N}$ \\
\hline $\mathbf{S}$ & NT & NT & $\mathbf{N}$ & $\mathbf{N}$ & PHZ & $\mathrm{HCN}$ & $\mathbf{N}$ & $\mathbf{N}$ \\
\hline $\mathbf{S}$ & NT & NT & $\mathbf{N}$ & $\mathbf{N}$ & PHZ & $\mathbf{N}$ & $\mathbf{N}$ & $\mathbf{N}$ \\
\hline$S$ & NT & NT & $\mathrm{N}$ & $\mathrm{N}$ & PHZ & $\mathrm{HCN}$ & $\mathbf{N}$ & $\mathbf{N}$ \\
\hline 0 & NT & NT & $\mathbf{N}$ & $\mathbf{N}$ & PHZ & $\mathrm{HCN}$ & $\mathbf{N}$ & $\mathbf{N}$ \\
\hline 0 & NT & NT & $\mathbf{N}$ & $\mathbf{N}$ & PHZ & $\mathrm{HCN}$ & $\mathrm{N}$ & $\mathbf{N}$ \\
\hline 0 & NT & NT & $\mathbf{N}$ & $\mathbf{N}$ & PHZ & $\mathrm{HCN}$ & $\mathbf{N}$ & $\mathbf{N}$ \\
\hline 0 & NT & NT & $\mathbf{N}$ & $\mathbf{N}$ & PHZ & $\mathrm{HCN}$ & $\mathbf{N}$ & $\mathbf{N}$ \\
\hline $\mathbf{F}$ & NBC & NT & $\mathbf{N}$ & $\mathbf{N}$ & $\mathbf{N}$ & $\mathbf{N}$ & $\mathbf{N}$ & $\mathbf{N}$ \\
\hline
\end{tabular}

Fig. 3. Phylogenetic tree of Pseudomonas chlororaphis PCL1606 and phylogenetically close members of sequenced Pseudomonas (Winsor et al. 2011) was constructed based on the analysis of two concatenated genes ( $g y r B$ and $r p o D ; 1,108$ nucleotides). The dendrogram was generated by the neighbor-joining method. Xanthomonas campestris pv. campestris was used as an outgroup. The bar indicates sequence divergence. Percent bootstrap values of more than $70 \%$ (from 1,000 replicates) are indicated at the nodes. The P. chlororaphis subgroup is boxed. Black cells: responses related to biocontrol; gray cells: response not related to biocontrol; white cells: NT, not tested; N, not detected. Source of strain isolation. S, soil; R, rhizosphere; F, phyllosphere; O, others. Biocontrol: biocontrol activity against soilborne fungal root pathogens. BC, biocontrol response; NBC, no biocontrol response; $\mathrm{P}$, phytopathogen. Antifungal antagonism: A, antifungal activity and NA, no antifungal activity. Presence of DNA sequences related to antifungal antibiotics: HPR, 2-hexyl, 5-propyl resorcinol; PRN, pyrrolnitrin; HCN, hydrogen cyanide; PHZ, phenazines; PLT, pyoluteorin; DAPG, diacetyl phloroglucinol. 
plasmid revealed a high identity and similar arrangement to dar genes that have been previously described in $P$. chlororaphis subsp. aurantiaca BL915, $P$. chlororaphis subsp. aureofaciens 30-84, and P. chlororaphis 06 (Figs. 1 and 2). However, $\operatorname{dar} B$ sequences exhibited a lower degree of similarity when compared with other microorganisms that were also obtained from soil and water environments, which suggest that these dar sequences are highly specific to the analyzed Pseudomonas spp. Additional phylogenetic studies showed that both housekeeping and $d a r B$ genes from PCL1606 were highly conserved among the $P$. chlororaphis subgroup strains examined. However, the phylogeny of dar genes was not congruent with bacterial taxonomy. Moreover, dar genes in P. chlororaphis were phylogenetically distant from dar genes in other Pseudomonas spp., perhaps as a result of horizontal gene transfer (Fig. 3). The P. chlororaphis subgroup is one of the nine subgroups that belong to the more complex $P$. fluorescent group (Mullet et al. 2010). The phylogenetic relationship of the strains used in this study indicates that PCL1606 shares common characteristics with the analyzed strains from the $P$. chlororaphis subgroup, such as isolation source, biocontrol activity, antifungal antagonism, and the presence of sequences that typically encode for antifungal antibiotics (Fig. 3). Taken together, these results suggest that the strain may be renamed P. chlororaphis PCL1606. In the same phylogenetic analysis, poor clustering of other strains from the $P$. fluorescens group could suggest the necessity of a taxonomic revision of these species, as previously proposed (Mullet et al. 2010).

The recently published genomes of some plant-associated Pseudomonas strains (Loper et al. 2012) allowed for a deeper analysis of the $P$. chlororaphis PCL1606 genome. The putative protein products and domain analyses of the $\operatorname{dar} A, \operatorname{dar} B, \operatorname{dar} C$, $d a r S$, and $d a r R$ genes confirmed putative functions for each of the dar genes. darA and darB play an important role in HPR production, with darA functioning as a diacyl resorcinol-condensing enzyme and $\operatorname{dar} B$ functioning as a $\beta$-ketoacyl synthase

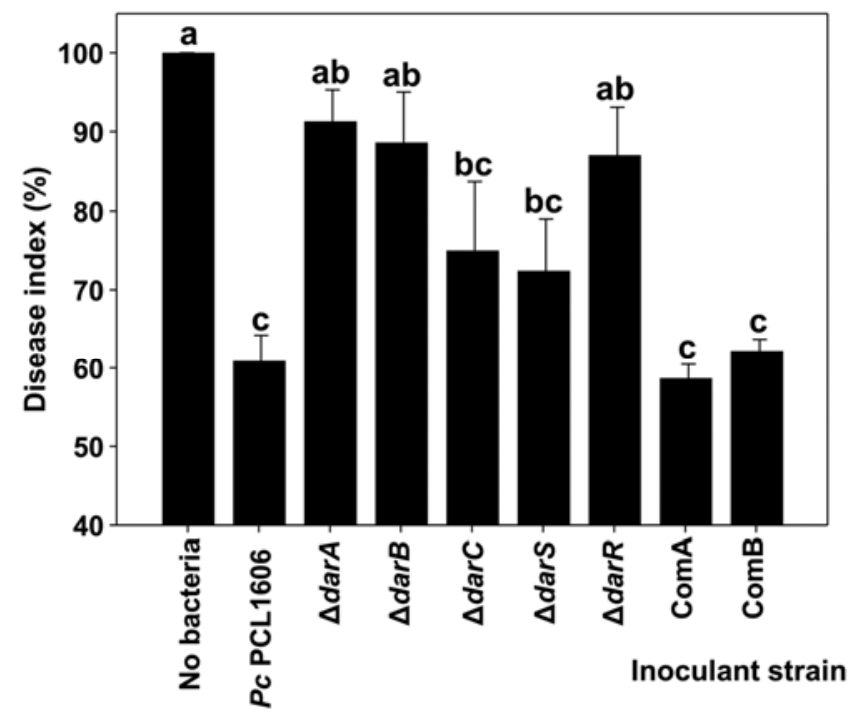

Fig. 4. Biocontrol of Rosellinia necatrix-induced white root rot in avocado plants resulting from the Pseudomonas chlororaphis PCL1606 that underwent insertional mutagenesis of their dar genes and by derivative strains that had been complemented with each respective plasmid (ComA and ComB) was measured. Roots from commercial 6-month-old avocado plants were inoculated with the derivative strains before being transferred to potting soil that was infested with $R$. necatrix. Plants were scored as sick or healthy at 18 to 21 days after bacterization. Data were analyzed for significance using an arcsine square root transformation with analysis of variance followed by Fisher's least significant difference test $(P=0.05)$. Values with different letter indications denote a statistically significant difference.
III enzyme that condenses two $\beta$-ketoacyl thioesthers derived from fatty acids (Nowak-Thompson et al. 2003; Pohanka et al. 2006). The protein FabH has a similar function (3-ketoacylACP synthase III) and shares conserved residues with DarB that are specific for protein-binding pockets. However, several differences allow these two proteins to be easily distinguished (Nowak-Thompson et al. 2003). darC has features of an ACP, which is a carrier of acyl intermediates during fatty acid synthesis (Biers and Gong 2007). In contrast, the two putative regulatory sequences represented by $\operatorname{dar} S$ and $\operatorname{darR}$ were present in all of the analyzed bacteria and exhibited a relatively high sequence identity (73 to $83 \%$ ). The predicted DarS and DarR proteins are similar to transcriptional regulators of the AraC/XylS family and, therefore, were proposed as putative regulators of HPR production. Thus, the presence of genes belonging to this family of transcriptional regulators among the analyzed genomes of Pseudomonas strains would suggest a wider regulatory role in addition to HPR production.

Mutagenesis combined with complemented mutants to restore the phenotype (Thomashow et al. 1997) has been previously used to demonstrate that antibiotics produced by $\mathrm{Pseu}$ domonas spp. play an important role in the biological control of plant diseases (Anjaiah et al. 1998; Chin-A-Woeng et al. 1998; Cronin et al. 1997; Hokeberg et al. 1998; Keel et al. 1990; Thomashow and Weller 1988; Vincent et al. 1991). To elucidate the role of each individual dar gene that was detected in PCL1606, insertional mutagenesis was performed. The degree of antagonism displayed by the mutants was clearly correlated with HPR production based on the lack of fungal antagonism in the derivative $\triangle d a r A$ and $\triangle d a r B$ strains; this result confirm the crucial role of $\operatorname{dar} A$ and $\operatorname{dar} B$ in HPR production. In contrast, disrupting $\operatorname{dar} C$ does not affect HPR production, which corresponds to its proposed putative function as an ACP. The continued production of HPR might result from other proteins with similar functions that are present in the genome and may complement the function of DarC protein, as observed in

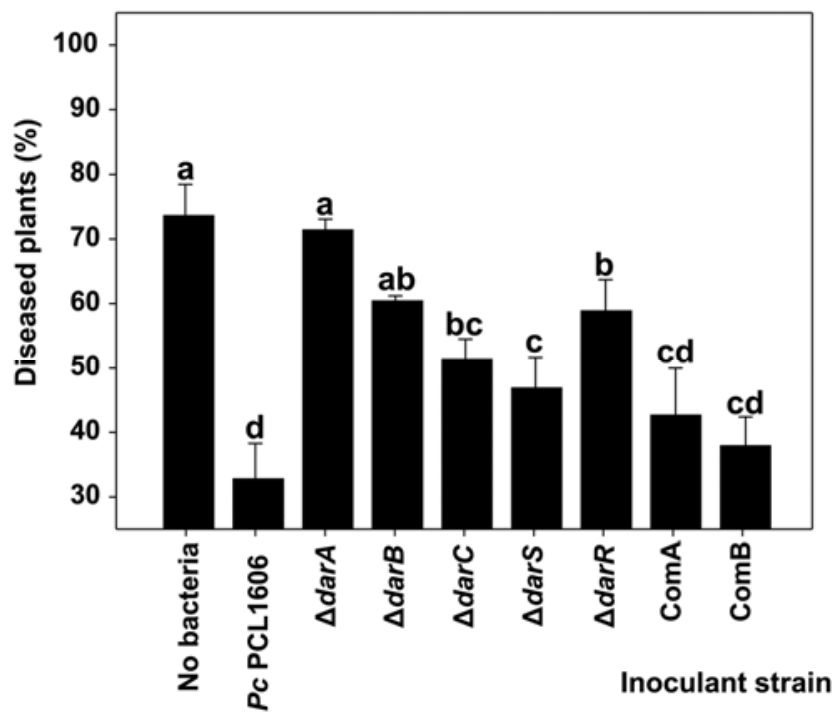

Fig. 5. Biocontrol of Fusarium oxysporum f. sp. radicis-lycopersiciinduced tomato foot and root rot resulting from the Pseudomonas chlororaphis PCL1606 that underwent insertional mutagenesis of their dar genes and by derivative strains that had been complemented with each respective plasmid (ComA and ComB) was measured. Tomato seed were coated with bacteria prior to being grown in soil infested with Fusarium spores. Plants were scored as healthy or sick after 21 days of growth. Data were analyzed for significance using an arcsine square root transformation with analysis of variance followed by Fisher's least significant difference test $(P=0.05)$. Values of bars with different letter designations represent a statistically significant difference. 
a previous study involving the heterologous expression of a darC-defective plasmid in Escherichia coli (Nowak-Thompson et al. 2003). Moreover, the antagonistic phenotype and HPR production were still observed in the $\Delta d a r S$ and $\Delta d a r R$ mutants (Table 2), which was also previously described for $P$. chlororaphis subsp. aurantiaca BL915 (Nowak-Thompson et al. 2003). As previously mentioned, the darS/R genes are proposed to encode a member of the AraC/XylS family of transcriptional regulators. This is a large family of regulators that is found in many bacteria and controls the expression of genes with diverse biological functions such as metabolism, stress response, and virulence (Gallegos et al. 1997; Ibarra et al. 2008). These genes generally function as activators; therefore, they would not be necessary for HPR production (Table 2) but could have an influence in the amount of HPR produced (Nowak-Thompson et al. 2003). Thus, the regulatory aspects of $d a r S / R$ could be extended to other biocontrol-related phenotypes that do not result from altered HPR production, such as the regulation of siderophores, superoxide response, stress adaptation, adhesion, and so on (Ibarra et al. 2008). The observation that $\Delta d a r S$ and $\Delta d a r R$ failed to protect the plant could support this hypothesis because HPR was still being produced in vitro. Additional experiments would need to be performed to elucidate any pleiotrophic phenotypes in the $\Delta d a r S$ and $\Delta$ darR mutants.

In contrast, previous studies involving derivative Tn5 mutants of P. chlororaphis PCL1606 (Cazorla et al. 2006) and their role in HPR production may now be revised based on the results described here. The PCL1606 derivative strain PCL1613 that is interrupted at a putative SAM-dependent methyltransferase showed reduced production of HPR, whereas the PCL1614 strain that is interrupted at a predicted glycine cleavage system $\mathrm{T}$ protein (GcvT) had no detectable production of HPR. The putative role of the SAM-dependent methyltransferase might be related to fatty acid biosynthesis in Pseudomonas spp. (Braun et al. 2010) and other bacteria (Biossier et al. 2006), and its disruption could affect the proposed pathway for the biosynthesis of HPR from fatty acid condensation (Nowak-Thompson et al. 2003). Similarly, the PCL1614 mutant in which $g c v T$ is disrupted may not produce enough of its product methyltetrahydrofolate, which is a very important cofactor in a variety of metabolic pathways, including the metabolism of glycine, serine, or pyrimidines, and even the generation of ATP (Vazquez et al. 2011). Moreover, the GcvT protein might also be involved in the metabolism of fatty acids (Vanden Boom et al. 1991). It seems likely that this derivative strain would be a pleiotrophic mutant with several pathways affected in addition to the biosynthetic pathway of the HPR production but additional experiments are needed to support this hypothesis.

These altered phenotypes related to HPR production could be restored after complementation experiments. Plasmids harboring the corresponding undisrupted gene were introduced into the derivative mutants $\triangle d a r A$ and $\Delta d a r B$, which generated their antagonistic derivatives ComA and ComB, respectively. These complemented strains exhibited normal growth patterns (data not shown) and displayed both antagonism and production of HPR (Fig. 4). The polar effects observed when $\operatorname{dar} B$ was inserted into the $\triangle$ dar $B$ derivative strain can be discarded because complementation with the $\operatorname{dar} B$ gene restored HPR production.

The biocontrol abilities of bacteria depend on the aggressiveness of their root colonization, the systemic resistance of the plant, and the production of diffusible or volatile antifungal antibiotics (Haas and Keel 2003; Lugtenberg and Kamilova 2009). The effectiveness of using antibiotics in biocontrol and, more generally, in microbial interactions has often been questioned due to the indirect nature of the supporting evidence and the per- ceived constraints to antibiotic production in rhizosphere environments (Raaijmakers et al. 2002). Additionally, it has recently been reported that antibiotics play important roles as signaling molecules and respond to the needs of the plant and the rhizosphere environment (Combes-Meynet et al. 2011; Jousset et al. 2011; Rochat et al. 2010). However, antibiotic compounds produced by root-colonizing fluorescent pseudomonads could play a significant role in suppressing soilborne diseases in crops (Dowling and O'Gara 1994). To confirm the role of HPR in biocontrol, two different experimental systems were used (avocado- $R$. necatrix and tomato-F. oxysporum) (Figs. 4 and 5). All of the derivative strains resulted in reduced protection against avocado white root rot or tomato foot and root rot when compared with the biocontrol wild-type strain, PCL1606. Only the non-HPR-producing derivative strains, $\Delta d a r A$ and $\triangle d a r B$, and the derivative strain $\Delta d a r R$, in which a putative regulator is impaired, were unable to protect the plants against the soilborne fungal pathogens assayed here. However, complementation of the disrupted genes with the HPR-producing ComA and ComB strains restored plant protection in the biocontrol experiments. Decreased protection was observed in both experimental systems when the HPR-producing $\Delta$ darR derivative was applied, which support a possible regulatory role for the darR gene in HPR production. However, darR could also be involved in other biocontrol-related phenotypes.

Related to the root conditions involved in producing HPR when assessing biocontrol by P. chlororaphis PCL1606, 5-alkylresorcinols induced DNA cleavage in vitro in the presence of $\mathrm{O}_{2}$ and $\mathrm{Cu}^{2+}$ at alkaline $\mathrm{pH}$ (Pohanka et al. 2006). Whether this is also relevant in the rhizosphere, including under the conditions of our biocontrol assays, is unknown and will deserve further work. Microaerobic conditions may prevail in the rhizosphere (Højberg et al. 1999). Copper is present in minute amounts in soils but, in many cropped soils, it has been used extensively to control diseases. Many soils are alkaline and, in the other soils, the roots can raise $\mathrm{pH}$ locally, especially when nitrogen is taken up as nitrate (Hinsinger et al. 2003).

In conclusion, this study has revealed the role of $\operatorname{dar} A$ and darB genes in HPR production by P. chlororaphis PCL1606. Additionally, HPR production is a major factor in the antagonistic phenotype, and this study demonstrates the crucial role of HPR in the biocontrol activity of P. chlororaphis PCL1606.

\section{MATERIALS AND METHODS}

Microorganisms, culture, and conditions.

The bacterial strains used in this study are listed in Table 3. King's medium B (KB) (King et al. 1954) was used to culture Pseudomonas strains at $25^{\circ} \mathrm{C}$. Luria-Bertani (LB) (Bertani $1951)$ medium was used to culture $E$. coli strains at $37^{\circ} \mathrm{C}$. The bacterial strains were stored at $-80^{\circ} \mathrm{C}$ in $\mathrm{LB}$ with $10 \%$ dimethyl sulfoxide. The media were supplemented with kanamycin $(50 \mu \mathrm{g} / \mathrm{ml})$, ampicillin $(100 \mu \mathrm{g} / \mathrm{ml})$, or gentamicin $(30 \mu \mathrm{g} / \mathrm{ml})$.

All fungal strains used in this study (Table 3 ) were grown at $25^{\circ} \mathrm{C}$ on potato dextrose agar (PDA) (Difco Laboratories, Detroit) or KB plates. $R$. necatrix was stored at $4^{\circ} \mathrm{C}$ as previously described (Gutierrez-Barranquero et al. 2012), and $F$. oxysporum was stored in $10 \%$ glycerol at $-80^{\circ} \mathrm{C}$.

The plasmids constructed in this study are listed in Table 1.

\section{Antagonism.}

The antagonistic activity of the various strains was tested as previously described (Cazorla et al. 2006; Geels and Schippers 1983). The initial screening for in vitro antifungal activity against $R$. necatrix $\mathrm{CH} 53$ and $F$. oxysporum $\mathrm{f}$. sp. radicis-lycopersici ZUM2407 (Table 3) was performed on KB and PDA plates as follows: a $0.6-\mathrm{cm}$-diameter mycelium disk from a 5 - 
day-old fungal culture was placed in the center of a petri dish at $24^{\circ} \mathrm{C}$, and the bacterial strains were inoculated at a distance of approximately $3 \mathrm{~cm}$ from the fungus. Bacterial strains that inhibited mycelial growth after 5 days, as judged by a growth inhibition zone, were considered antagonistic.

\section{Production of the antifungal antibiotic \\ 2-hexyl, 5-propyl resorcinol.}

The strains used in this study were tested for the production of the antifungal antibiotic HPR, as previously described (Cazorla et al. 2006). To detect HPR, cell-free supernatants from 5-day-old liquid $\mathrm{KB}$ cultures of the corresponding strains were extracted with chloroform/methanol (2:1, [vol/ vol]). The extracted material was fractionated in chloroform/ acetone (9:1, [vol/vol]) via TLC using silica RP-18F $254 \mathrm{~S}$ TLC plates (Merck AG, Darmstadt, Germany). After drying, spots were detected on the chromatogram under UV light at 254 $\mathrm{nm}$, and $R f$ values were calculated. Antibiotic production was also determined by spraying these TLC plates with diazotized sulfanilic acid and watching for a characteristic color change (Whistler et al. 2000). Spots with an $R f$ value of approximately 0.9 to 0.95 that were brown to dark green in color were considered positive for HPR. P. chlororaphis subsp. aurantiaca BL915 and P. chlororaphis PCL1606 were used as references for antibiotic production.

\section{Determination of dar homologous sequences in $P$. chlororaphis PCL1606.}

To detect the presence of sequences that were homologous to dar genes in P. chlororaphis PCL1606, standard protocols for DNA manipulation and PCR amplification were used (Sambrook and Russell 2001). Specific PCR primers were designed using the Primer3 software (Supplementary Table S1) based on the sequences described for the five dar genes present in $P$. chlororaphis subsp. aurantiaca BL915 (NCBI, accession number AY135187) (Nowak-Thompson et al. 2003). Genomic DNA was extracted from PCL1606 for use as the template in the various amplification reactions and from $P$. chlororaphis subsp. aurantiaca BL915 for use as a positive control with the Genomic DNA Purification JETFLEX kit (Genomed GmbH, Löhne, Germany). Amplifications were performed in a final volume of $25 \mu \mathrm{l}$ that contained $10 \mu \mathrm{M}$ each primer, $2.5 \mathrm{U}$ of GoTaq Flexi DNA polymerase (Promega Corp., Madison, WI, U.S.A.), a dNTP mixture $(250 \mu \mathrm{M}$ each dNTP), $2 \mathrm{mM} \mathrm{MgCl}$, $1 \times$ GoTaq Flexi buffer, and approximately $50 \mathrm{ng}$ of template DNA. The PCR amplification conditions consisted of an initial denaturation for $2 \mathrm{~min}$ at $94^{\circ} \mathrm{C}$; followed by 30 cycles of denaturation at $94^{\circ} \mathrm{C}$ for $1 \mathrm{~min}$, annealing at $61^{\circ} \mathrm{C}$ for $1 \mathrm{~min}$, and extension at $72^{\circ} \mathrm{C}$ for $1 \mathrm{~min}$; and a final extension at $72^{\circ} \mathrm{C}$ for $10 \mathrm{~min}$. The PCR products were analyzed for size and quantity by electrophoresis on $1 \%$ agarose gels in Tris-acetate-EDTA buffer $(40 \mathrm{mM}$ Tris- $\mathrm{HCl}$ and 1 mM EDTA, $\mathrm{pH}$ 8) and ethidium bromide was used at a concentration of $1 \mu \mathrm{l} / \mathrm{ml}$ to visualize the DNA bands.

\section{Screening the $P$. chlororaphis PCL1606 genomic library.}

To obtain genomic clones that contained sequences homologous to dar, a phage library was constructed from P. chlororaphis PCL1606 DNA using a library of phagemids ( $\lambda$ BlueSTAR Vector Cloning Kit; Novagen, Darmstadt, Germany)

Table 3. Bacterial and fungal strains used in this study

\begin{tabular}{|c|c|c|}
\hline Strain & Relevant characteristics ${ }^{\mathbf{a}}$ & Reference, source ${ }^{b}$ \\
\hline \multicolumn{3}{|c|}{ Bacterial strains } \\
\hline \multicolumn{3}{|c|}{$\begin{array}{l}\text { Pseudomonas chlororaphis } \\
\text { subsp. aurantiaca }\end{array}$} \\
\hline \multirow{2}{*}{\multicolumn{3}{|c|}{ 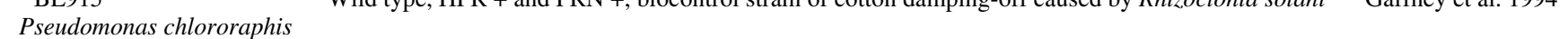 }} \\
\hline & & \\
\hline PCL1606 & $\begin{array}{l}\text { Wild type, isolated from avocado rhizosphere, HPR }+ \text {, antagonistic biocontrol strain of avocado } \\
\text { white root rot caused by Rosellinia necatrix }\end{array}$ & Cazorla et al. 2006 \\
\hline$\Delta d a r A$ & $\begin{array}{l}\text { PCL1606 derivative insertional mutant in darA gene by insertion of the plasmid p } \Delta \text { DARA526, } \\
\text { HPR }-, \mathrm{Km}^{\mathrm{r}}\end{array}$ & This study \\
\hline$\Delta d a r B$ & $\begin{array}{l}\text { PCL1606 derivative insertional mutant in } \operatorname{darB} \text { gene by insertion of the plasmid } \mathrm{p} \Delta \mathrm{DARB} 379 \text {, } \\
\text { HPR }-, \mathrm{Km}^{\mathrm{r}}\end{array}$ & This study \\
\hline$\Delta d a r C$ & $\begin{array}{l}\text { PCL1606 derivative insertional mutant in } \operatorname{darC} \text { gene by insertion of the plasmid } \mathrm{p} \Delta \mathrm{DARC} 153 \text {, } \\
\mathrm{HPR}+, \mathrm{Km}^{\mathrm{r}}\end{array}$ & This study \\
\hline$\Delta d a r S$ & $\begin{array}{l}\text { PCL1606 derivative insertional mutant in darS gene by insertion of the plasmid p } \Delta \text { DARS351, } \\
\text { HPR }+, \mathrm{Km}^{\mathrm{r}}\end{array}$ & This study \\
\hline$\Delta d a r R$ & $\begin{array}{l}\text { PCL1606 derivative insertional mutant in } \operatorname{dar} R \text { gene by insertion of the plasmid } \mathrm{p} \Delta \mathrm{DARR} 354 \text {, } \\
\mathrm{HPR}+, \mathrm{Km}^{\mathrm{r}}\end{array}$ & This study \\
\hline ComA & $\Delta$ darA transformed with the plasmid pCOMA, $\mathrm{HPR}+. \mathrm{Gm}^{\mathrm{r}}$ and $\mathrm{Km}^{\mathrm{r}}$ & This study \\
\hline ComB & $\Delta d a r B$ transformed with the plasmid pCOMB, $\mathrm{HPR}+. \mathrm{Gm}^{\mathrm{r}}$ and $\mathrm{Km}^{\mathrm{r}}$ & This study \\
\hline \multicolumn{3}{|c|}{ Pseudomonas protegens } \\
\hline Pf-5 & $\begin{array}{l}\text { Wild type, DAPG }+, \text { PLT }+ \text {, and PRN }+ \text {, and biocontrol strain of cotton damping off caused by } \\
\text { Rhizoctonia solani }\end{array}$ & Ramette et al. 2011 \\
\hline \multicolumn{3}{|c|}{${ }^{2}$} \\
\hline DH5 $\alpha$ & General-purpose Escherichia coli host strain & Boyer \\
\hline ER1647 & $\begin{array}{l}\text { Lysogenic strain, used to screen a phage DNA library, } \mathrm{F}^{-} \text {fhuA2 } \Delta(\text { lacZ)r1, supE44, hsdS } \\
\left(\mathrm{r}_{\mathrm{k} 12^{-}}-\mathrm{m}_{\mathrm{k} 12^{-}}\right), \mathrm{Sm}^{\mathrm{r}}, \mathrm{Tet}^{\mathrm{r}}\end{array}$ & Novagen \\
\hline BM25.4 & $\begin{array}{l}\text { Nonlysogenic strain, used to recover the plasmids from a phage library, supE thi } \Delta \text { (lac-proAB), } \\
h s d \mathrm{R}\left(\mathrm{r}_{\mathrm{k} 12}-\mathrm{m}_{\mathrm{k} 12}+\right), \mathrm{Cm}^{\mathrm{r}}, \mathrm{Km}^{\mathrm{r}}\end{array}$ & Novagen \\
\hline \multicolumn{3}{|c|}{ (1) } \\
\hline \multicolumn{3}{|c|}{$\begin{array}{l}\text { Fusarium oxysporum f. sp. } \\
\text { radicis-lycopersici }\end{array}$} \\
\hline ZUM2407 & Causes crown and foot rot of tomato & IPO-DLO \\
\hline \multicolumn{3}{|c|}{ Rosellinia necatrix } \\
\hline CH53 & Wild type, isolated from avocado trees with symptoms of white root rot; high virulence & Lopez-Herrera \\
\hline
\end{tabular}


according to the manufacturer's instructions. Briefly, $20 \mu \mathrm{g}$ of genomic DNA from PCL1606 was partially digested with the Sau3A restriction enzyme (Roche Diagnostics, Mannheim, Germany). The resulting fragments with sizes between 9 and $23 \mathrm{~kb}$ were inserted into a BamHI linearized pBlueSTAR-1 vector and ligated with T4 ligase (Roche Diagnostics). Finally, the plasmids were packaged into phages according to the manufacturer's instructions.

To detect and isolate DNA that contained sequences that were homologous to dar genes, Southern blot analyses were performed (Sambrook and Russell 2001). First, a PCR-amplified fragment that consisted of $1,009 \mathrm{bp}$ of the $P$. chlororaphis subsp. aurantiaca BL915 darB gene was obtained as previously described by using the pBL1009F and R primers. After sequencing and verification, this DNA was used as a probe to screen the plaques that formed on the lysogenic E. coli ER1647 strain. Of the 3,000 plaques screened, two phagemids hybridized to the probe. Phage infections of the nonlysogenic E. coli BM25.8 strain were than performed to obtain two independent plasmids (pCGNOV-1 and pCGOCT-1). The nonhybridizing plasmid pCGNOV-3 was used as control. To select those plasmids that contained sequences homologous to other dar genes, Southern blots were performed. PCR-amplified DNA sequences of $\operatorname{darA}(821 \mathrm{bp})$ and $\operatorname{darC}(223 \mathrm{bp})$ from $P$. chlororaphis subsp. aurantiaca BL915 were obtained using specific primers and were sequenced to verify their homology to dar genes. These amplified DNA sequences were then used as probes in the subsequent Southern blot assays, and the pCGNOV-1 plasmid was selected for further studies.

The DNA from pCGNOV-1 was sequenced by Macrogen (Macrogen Inc., Seoul, South Korea) and amplified in both directions from the $d a r B$ gene sequence using the "primerwalking" technique. The resulting sequences were then assembled using the DNAM software (Lynnon Corp., Quebec, Canada). Finally, the pCGNOV-1 sequence was deposited in the NCBI database under the accession number JQ663992.

\section{Bioinformatics.}

To analyze the genomic DNA sequences obtained, the NCBI (Bethesda, MD, U.S.A.) database was searched. BLAST algorithms (Altschul et al. 1990) were used to analyze sequence similarity and conserved domains. Protein tools from the European Molecular Biology Laboratory-European Bioinformatics Institute (EMBL-EBI) and the Pfam database were used. Restriction maps were constructed and analyzed using the JustBio website and primers were designed using Primer3 online software (Broad Institute, Cambridge, MA, U.S.A.). To map the chromosomal fragment that was cloned into pCGNOV-1, a comparison analysis was performed using the $P$. chlororaphis subsp. aurantiaca BL915 DNA sequences that are present in the NCBI database (accession number AY135187).

The pCGNOV-1 sequence was analyzed in the NCBI GenBank database to identify possible dar-homologous genes, particularly the sequence corresponding to the $\operatorname{dar} B$ gene. In silico analyses comparing $P$. chlororaphis PCL1606 sequences to other microorganisms were performed using the tools previously described along with the dar cluster sequence of $P$. chlororaphis subsp. aurantiaca BL915 and the completely sequenced genomes of the biocontrol strains $P$. chlororaphis 06 (GenBank accession number AHOT01000006.1), P. chlororaphis subsp. aureofaciens 30-84 (GenBank accession number AHHJ01000007.1), P. protegens Pf-5 (GenBank accession number CP000076), Pf-01 (GenBank accession number CP000094), and SBW25 (GenBank accession number AM181176) as references.

Additional complete genomes from other Pseudomonads and other microorganisms commonly used in phylogenetic studies have been obtained from GenBank and Pseudomonas databases (Altschul et al. 1990; Winsor et al. 2011).

\section{Phylogenetic studies in P. chlororaphis PCL1606.}

The phylogenetic analysis of $P$. chlororaphis PCL1606 and other strains belonging to the genus Pseudomonas was performed using multilocus sequence analysis of a concatenated data set of $r p o D$ and $g y r B$ genes (partial sequences). The phylogenetic analysis of the $\operatorname{dar} B$ sequences was similarly performed but included additional microorganisms that were present in the database. In both analyses, multiple alignments were performed with ClustalW (Larkin et al. 2007), and a phylogenetic tree was constructed using the neighbor-joining method (Saitou and Nei 1987). The percentage of replicate trees in which the associated taxa were clustered in the bootstrap test (1,000 replicates) is shown next to the branches (Felsenstein 1985). All positions containing gaps and missing data were eliminated from the dataset (complete deletion option). The concatenated sequences of the housekeeping genes yielded an alignment with 1,108 sites that could be compared among all strains. The complete $\operatorname{dar} B$ sequence was 1,110 to 1,155 nucleotides. The phylogenetic analyses were conducted using MEGA 5 (Tamura et al. 2011).

\section{Construction of $P$. chlororaphis PCL1606 mutants and derivative strains.}

PCR, cloning, and plasmid purification were performed following standard procedures (Sambrook and Russell 2001). $P$. chlororaphis PCL1606 dar genes were inactivated by insertional mutagenesis and the resulting production of HPR production was measured. To accomplish this inactivation, disruption vectors were inserted into the various dar homologous gene ORF by single-crossover homologous recombination. To construct the integrative plasmids (Table 1), DNA fragments from the different ORF within the genomic cluster were obtained using specific PCR primers (pMut primers) and the genomic clone pCGNOV-1 as the template. The amplified DNA fragments were then cloned into the pCR2.1 TOPO vector ( $\triangle$ DAR plasmids) (Table 1 ). These integrative plasmids were then transformed into wild-type PCL1606 by standard electroporation (Choi et al. 2006). Five colonies from each independent transformation assay were randomly selected, and the correct insertion and orientation of the plasmid within the target gene were confirmed by PCR. Southern blot analysis using dar sequences and kanamycin sequences (data not shown) permitted the selection of one single-copy transformant of each sitedirected mutant for further analysis. The mutants were named $\triangle d a r A, \Delta d a r B, \Delta d a r C, \Delta d a r S$, and $\Delta d a r R$ (Table 3). The insertional mutants were selected in the presence of kanamycin. Additionally, the mutants were analyzed for appropriate insertion using PCR and Southern blot analyses with the antibiotic resistance cassette or partial dar gene sequences as probes (data not shown) to confirm gene disruption and to select single-copy transformants. The $R$. necatrix- and $F$. oxysporum $\mathrm{f}$. sp. radicis-lycopersici-induced production of HPR and the resulting fungal antagonism were evaluated for each derivative strain as previously described. Additionally, the growth of each strain on M9 minimal medium (Rainey 1999; Sambrook et al. 1989) was determined, and optical density and bacterial counts of the derivative mutants were compared with those of the wild-type strain.

\section{Complementation experiments.}

Two plasmids containing the homologous darA and $\operatorname{dar} B$ genes were constructed for complementation of the mutant $d a r$ genes that displayed defective HPR production $(\triangle d a r A$ and $\triangle d a r B)$. DNA fragments containing darA or $\operatorname{dar} B$ were ampli- 
fied by PCR from PCL1606 with specific primers that added two additional restriction sites (HindIII to the $5^{\prime}$ end and XbaI to the $3^{\prime}$ end). These fragments were amplified using a highfidelity Taq polymerase (Expand Long Range, dNTPack; Roche Diagnostics), and the PCR product was cloned into the pGEM-T vector (Promega Corp.). The DNA fragments were then digested with HindIII and XbaI and cloned into the HindIII/XbaI site of pBBR1MCS-5 (Kovach et al. 1995) to produce the plasmids pCOMA and pCOMB (Table 1). These DNA fragments were fused near the polylinker and downstream of the lac $Z$ promoter in pBBR1MCS-5, which acts as a constitutive promoter in $P$. fluorescens. These complementing plasmids, pCOMA and pCOMB, were then introduced into the $\triangle d a r A$ and $\triangle d a r B$ derivative strains ComA and ComB, respectively (Table 3 ), using standard electroporation. Colony selection was performed on LB medium plates supplemented with kanamycin and gentamicin, and the appropriate phenotypes were evaluated.

\section{Biocontrol against tomato root rot.}

Biocontrol trials in the tomato- $F$. oxysporum f. sp. radicislycopersici system were conducted as previously described (Cazorla et al. 2006; Chin-A-Woeng et al. 1998). One-third of a 7-day-old PDA plate culture of $F$. oxysporum f. sp. radicislycopersici ZUM2407 was homogenized and inoculated in 1liter Erlenmeyer flasks containing $200 \mathrm{ml}$ of potato-dextrose broth. After 3 days of growth at $28^{\circ} \mathrm{C}$ under aeration $(110$ $\mathrm{rev} / \mathrm{min}$ ), the fungal material was placed on top of sterile glass wool and the filtrate was adjusted to $5 \times 10^{5}$ spores $/ \mathrm{ml}$. For soil inoculation, spore suspensions were mixed thoroughly with potting soil to a final concentration of $3.2 \times 10^{6}$ spores $/ \mathrm{kg}$.

Tomato (Solanum lycopersicum L.) seed ('Moneymaker') were coated with bacteria by dipping the seed in a mixture of $1 \%$ (wt/vol) methylcellulose (Sigma-Aldrich, St. Louis) and bacteria at $10^{9} \mathrm{CFU} / \mathrm{ml}$ in phosphate-buffered saline buffer. Coated seed were dried in a sterile stream of air. One seed was sown in each pot that contained $25 \mathrm{~g}$ of soil at approximately $1.5 \mathrm{~cm}$ deep. Ten sets of 10 plants each were included in each treatment. The seedlings were grown in a greenhouse at $24^{\circ} \mathrm{C}$ with $70 \%$ relative humidity and $16 \mathrm{~h}$ of daylight and were watered from the bottom. Diseased plants were counted only after a considerable fraction of the untreated control plants (above 60\%) showed symptoms, which usually occurred 18 days after sowing. The plants were removed from the soil and washed, and the plant roots were examined for tomato crown and root rot symptoms, which were detected by the presence of root browning and lesion formation. Roots without any disease symptoms were designated as healthy.

\section{Biocontrol assays against avocado white root rot.}

Biocontrol assays against avocado white root rot were performed using the avocado- $R$. necatrix system, as previously described (Cazorla et al. 2006). Six-month-old avocado plants were obtained from Brokaw nurseries (Brokaw España, S.L., Vélez-Málaga, Spain). The roots from the avocado plants were disinfected by immersion in $0.1 \% \mathrm{NaOCl}$ for $20 \mathrm{~min}$ and then washed and bacterized following the method previously described (Lugtenberg et al. 1994), with slight modifications. The roots of the avocado plants were immersed in a suspension of the bacterial isolate $\left(10^{9} \mathrm{CFU} / \mathrm{ml}\right)$ or in sterile tap water for $20 \mathrm{~min}$. Any excess bacterial suspension was allowed to drip off, after which the seedlings were placed into pots containing $30 \mathrm{~g}$ of wet potting soil (Jongkind Grond B.V., Aalsmeer, The Netherlands) and infected with $R$. necatrix using wheat grains (four infected grains per pot) as described by Freeman and associates (1986). Five sets of 10 avocado seedlings each were tested per treatment. The seedlings were grown in a chamber at $24^{\circ} \mathrm{C}$ and $70 \%$ relative humidity with $16 \mathrm{~h}$ of daylight and were watered twice per week. The number of diseased seedlings was determined 21 days after bacterization.

Because it was difficult to monitor the symptoms on hardened avocado roots due to the overgrowth of $R$. necatrix, aerial symptoms were recorded on a scale of 0 to 3 and a normalized disease index was calculated using the previously described formula (Cazorla et al. 2006).

\section{Statistical methods.}

The data were statistically analyzed using an analysis of variance (Sokal and Rohlf 1986), followed by Fisher's least significant difference test $(P=0.05)$ using the SPSS 12 software (SPSS Inc., Chicago). All experiments were performed at least two times.

\section{ACKNOWLEDGMENTS}

This research was supported by the Spanish Plan Nacional I + D + I Grants AGL 2008-05453-C02-01 and AGL11-30354-C02-01 and was cofinanced by the European Union (FEDER). C. E. Calderón was supported by a grant from FPI, Ministerio de Ciencia e Innovación, Spain. We thank postgraduate students D. J. Ruiz and R. Martín for their helpful assistance in working with the $P$. chlororaphis PCL1606 DNA library.

\section{LITERATURE CITED}

Altschul, S. F., Gisch, W., Miller, W., Myers. E. W., and Lipman, D. J. 1990. Basic local alignment search tool. J. Mol. Biol. 215:403-410.

Anjaiah, V., Koedam, N., Nowak-Thompson, B., Loper, J. E., Hofte, M., Tambong, J. T., and Cornelis, P. 1998. Involvement of phenazines and anthranilate in the antagonism of Pseudomonas aeruginosa PNA1 and Tn5 derivatives toward Fusarium spp. and Pythium spp. Mol. PlantMicrobe Interact. 11:847-854.

Bertani, G. 1951. A method for detection of mutations using streptomycin dependence in Escherichia coli. Genetics 36:598-611.

Biers, D. M., and Gong, H. 2007. Acyl carrier proteins: Structure-function relationships in a conserved multifunctional protein family. Biochem. Cell Biol. 85:649-662.

Boissier, F., Bardou, F., Guillet, V., Uttenweiler-Joseph, S., Daffé, M., Quémard, A., and Mourey, L. 2006. Further insight into S-adenosylmethionine-dependent methyltransferases. Structural characterization of Hma, an enzyme essential for the biosynthesis of oxygenated mycolic acids in Mycobacterium tuberculosis. J. Biol. Chem. 281:4434-4445.

Boyer, H. W., and Roulland-Dussoix, D. 1969. A complementation analysis of the restriction and modification of DNA in Escherichia coli. J. Mol. Biol. 41:459-472.

Braun, S. D., Hofmann, J., Wensing, A., Ullrich, M. S., Weingart, H., Völksh, B., and Spiteller, D. 2010. Identification of the biosynthetic gene cluster for 3-methylarginine, a toxin produced by Pseudomonas syringae pv. syringae 22d/93. Appl. Environ. Microbiol. 76:25002508

Cazorla, F. M., Duckett, S., Bergström, E., Noreen, S., Odijk, R, Lugtenberg, B. J. J., Thomas-Oates, J., and Bloemberg, G. V. 2006. Biocontrol of avocado Dematophora root rot by antagonistic Pseudomonas fluorescens PCL1606 correlates with the production of 2-hexyl, 5-propyl resorcinol. Mol. Plant-Microbe Interact. 19:418-428.

Chin-A-Woeng, T. F. C., Bloemberg, G. V., and Lugtenberg, B. J. J. 1998. Biocontrol by phenazine-1-carboxamide-producing Pseudomonas chlororaphis PCL1391 of tomato root rot caused by Fusarium oxysporum f. sp. radicis-lycopersici. Mol. Plant-Microbe Interact. 11:1069-1077.

Choi, K.-H., Kumar, A., and Scheweizer, H. P. 2006. A 10-min method for preparation of highly electrocompetent Pseudomonas aeruginosa cells: Application for DNA fragment transfer between chromosomes and plasmid transformation. J. Microbiol. Methods 64:391-397.

Combes-Meynet, E., Pothier, J. F., Moënne-Loccoz, Y., and PrigentCombaret, C. 2011. The Pseudomonas secondary metabolite 2,4-diacetylphloroglucinol is a signal inducing rhizoplane expression of Azospirillum genes involved in plant-growth promotion. Mol. Plant-Microbe Interact. 24:271-284.

Cronin, D., Moënne-Loccoz, Y., Fenton, A., Dunne, C., Dowling, D. N., and O'Gara, F. 1997. Role of 2,4-diacetylphloroglucinol in the interac- 
tions of the biocontrol pseudomonad strain F113 with the potato cyst nematode Globodera rostochiensis. Appl. Environ. Microbiol. 63:13571361

Dowling, D. N., and O'Gara, F. 1994. Metabolites of pseudomonas involved in the biocontrol of plant disease. Trends Biotechnol.12:133 140

Felsenstein, J. 1985. Confidence limits on phylogenies: An approach using the bootstrap. Evolution 39:783-791.

Freeman, S., Sztejnberg, A., and Chet, I. 1986. Evaluation of Trichoderma as a biocontrol agent for Rosellinia necatrix. Plant Soil 94:163-170.

Gaffney, T. D., Lam, S. T., Ligon, J., Gates, K., Frazelle, A., Di Maio, J., Hill, S., Goodwin, S., Torkewitz, N., and Allshouse, A. M. 1994. Global regulation of expression of antifungal factors by a Pseudomonas fluorescens biological control strain. Mol. Plant-Microbe Interact. 7:455463.

Gallegos, M. T., Schleit, R., Bairoch, A., Hofmann, K., and Ramos, J. L. 1997. AraC/XylS family of transcriptional regulators. Microbiol. Mol. Biol. Rev. 61:393-410.

Geels, F. P., and Schippers, G. 1983. Selection of antagonistic fluorescent Pseudomonas spp., and their root colonization and persistence following treatment of seed potatoes. Phytopathology 108:193-206.

González-Sánchez, M. A., Pérez-Jiménez, R. M., Pliego, C., Ramos., de Vicente, A., and Cazorla, F. M. 2010. Biocontrol bacteria selected by a direct plant protection strategy against avocado white root rot show antagonism as a prevalent trait. J. Appl. Microbiol. 109:65-78.

Gutierrez-Barranquero, J. A., Pliego, C., Bonilla, N., Calderón, C. E., PérezGarcía, A., de Vicente, A., and Cazorla, F. M. 2012. Sclerotization as a long-term preservation method for Rosellinia necatrix strains. Mycoscience 53:460-465

Haas, D., and Défago, G. 2005. Biological control of soil-borne pathogens by fluorescent pseudomonads. Nat. Rev. Microbiol. 3:307-319.

Haas, D., and Keel, C. 2003. Regulation of antibiotic production in rootcolonizing Pseudomonas spp. and relevance for biological control of plant disease. Annu. Rev. Phytopathol. 41:117-153.

Hill, D. S., Stein, J. I., Torkewitz, N. R., Morse, A. M., Howell, C. R., Pachlatko, J. P., Becker, J. O., and Ligon, J. M. 1994. Cloning of genes involved in the synthesis of pyrrolnitrin from Pseudomonas fluorescens and role of pyrrolnitrin synthesis in biological control of plant disease. Appl. Environ. Microbiol. 60:78-85.

Hinsinger, P., Plassard, C., Tang, C., and Jaillard, B. 2003. Origins of rootinduced $\mathrm{pH}$ changes in the rhizosphere and their responses to environmental constraints: A review. Plant Soil 248:43-59.

Højberg, O., Schnider, U., Winteler, H. V., Sørensen, J. \& Haas, D. 1999 Oxygen-sensing reporter strain of Pseudomonas fluorescens for monitoring the distribution of low-oxygen habitats in soil. Appl. Environ. Microbiol. 65:4085-4093

Hokeberg, M., Wright, S. A. I., Svensson, M., Lundgren, L. N., and Gerhardson, B. 1998. Mutants of Pseudomonas chlororaphis defective in the production of an antifungal metabolite express reduced biocontrol activity. (Abstr.) Proceedings of the 1998 International Congress of Plant Pathology, Edinburgh, Scotland.

Ibarra, J. A., Pérez-Rueda, E., Segovia, L., and Puente, J. L. 2008. The DNA-binding domain as a functional indicator: The case of the AraC/XylS family of transcription factors. Genetica 133:65-76.

Jousset, A., Rochat, L., Lanoue, A., Bonkowski, M., Keel, C., and Scheu, S. 2011. Plants respond to pathogen infection by enhancing the antifungal gene expression of root-associated bacteria. Mol. Plant-Microbe Interact. 24:352-358.

Kanda, N., Isizaky, N., Inone, N., Oshima, M., and Handa, A. 1975. DB2073, a new alkylresorcinol antibiotic. I. Taxonomy, isolation and characterization. J. Antibiot. (Tokyo) 28:935-942.

Keel, C., Wirthner, P., Oberhansli, T., Voisard, C., Burger, Haas, D., and Défago, G. 1990. Pseudomonads as antagonists of plant-pathogens in the rhizosphere: Role of the antibiotic 2,4-diacetylphloroglucinol in the suppression of black root-rot of tobacco. Symbiosis 9:327-341.

King, E. O., Ward, M. K., and Raney, D. E. 1954. Two simple media for the demonstration of pyocyanin and fluorescein. J. Lab. Clin. Med. 44:301-0307.

Kitahara, T., and Kanda, N. 1975. DB-2073, a new alkylresorcinol antibiotic. II. The chemical structure of DB-2073. J. Antibiot. (Tokyo) 28:943-946.

Kovach, M. E., Elzer, P. H., Hill, D. S., Robertson, G. T., Farris, M. A., Roop, R. M., II., and Peterson, K. M. 1995. Four new derivatives of the broad-host-range cloning vector pBBR1MCS, carrying different antibiotic-resistance cassettes. Gene 166:175-176.

Larkin, M. A., Blackshields, G., Brown, N. P., Chenna, R., McGettigan, P. A., McWilliam, H., Valentin, F., Wallace, I. M., Wilm, A., Lopez, R., Thompson, J. D., Gibson, T. J., and Higgins, D. G. 2007. Clustal W and Clustal X version 2.0. Bioinformatics 23:2947-2948.

Loper, J. E., Hassan, K. A., Mavrodi, D. V., Davis II, E. W., Lim, C. K.,
Shaffer, B. T., Elbourne, L. D. H., Stockwell, V. O., Hartney, S. L., Breakwell, K., Henkels, M. D., Tetu, S. G., Rangel, L. I., Kidarse, T. A., Wilson, N. L., van de Mortel, J. E., Song, C., Blumhagen, R., Radune, D., Hostetler, J. B., Brinkac, L. M., Durkin, A. S., Kluepfel, D. A., Wechter, W. P., Anderson, A. J., Kim, Y. C., Pierson III, L. S., Lindow, S. E., Kobayashi, D. Y., Raaijmakers, J. M., Weller, D. M., Thomashow, L. S., Allen, A. E., and Paulsen, I. T. 2012. Comparative genomics of plant-associated Pseudomonas spp.: Insight into diversity and inheritance of traits involved in multitrophic interactions. PLoS Genet. 8:e1002784:1-27. Published online.

López-Herrera, C. J., and Zea-Bonilla, T. 2007. Effects of benomyl, carbendazim, fluazinam and thiophanate methyl on white root rot of avocado. Crop Prot. 26:1186-1192.

Lugtenberg, B., and Kamilova, F. 2009. Plant-growth-promoting rhizobacteria. Annu. Rev. Microbiol. 63:541-56.

Lugtenberg, B. J. J., de Weger, L. A., and Schippers, B. 1994. Bacterization to protect seeds and rhizosphere against disease. BCPC Monogr. 57:293-302.

Morrissey, J. P., Cullinane, M., Abbas, A., Mark, G. L., and O'Gara, F. 2004. Pages 637-670 in: Pseudomonas, Vol. 3. J.-L. Ramos, ed. Kluwer Academic/Plenum Publishers, New York.

Mullet, M., Lalucat, J., and García-Valdés, E. 2010. DNA sequence-based analysis of the Pseudomonas species. Environ. Microbiol. 12:15131530

Nowak-Thompson, B., Philip E., Hammer, D., Hill, D. S., Staffords, J., Torkewitz, N., Gaffney, T. D., Lam, S. T., Molnár, I., and Ligon, J. M. 2003. 2,5-diakylresorcinol biosynthesis in Pseudomonas aurantiaca: Novel head-to-head condensation of two fatty acid-derived precursors. J. Bacteriol. 185:860-869.

Pliego, C., Kanematsu, S., Ruano-Rosa, D., de Vicente, A., López-Herrera, C., Cazorla, F. M., and Ramos, C. 2009. GFP sheds light on the infection process of avocado roots by Rosellinia necatrix. Fungal Genet. Biol. 46:137-145.

Pliego, C., Ramos, C., de Vicente, A., and Cazorla, F. M., 2011. Screening for candidate bacterial biocontrol agents against soilborne fungal plant pathogens. Plant Soil 340:505-520.

Pliego, C., López-Herrera, C., Ramos, C., and Cazorla, F. M. 2012. Developing tools to unravel the biological secrets of Rosellinia necatrix, and emergent threat to woody crops. Mol. Plant. Pathol. 13:226-239.

Pohanka, A., Levenfors, J., and Broberg, A. 2006. Antimicrobial dialkylresorcinols from Pseudomonas sp. Ki19. J. Nat. Prod. 69:654-657.

Purseglove, J. W. 1968. Persea Americana Mill. Pages 192-198 in: Tropical Crops: Dicotyledons. 1. Longmans, Green \& Co. Ltd., London.

Raaijmakers, J. M., Vlami, M., and de Souza, J. T. 2002. Antibiotic production by bacterial biocontrol agents. Antonie Leeuwenhoek 81:537547.

Raaijmakers, J. M., de Brujin, I., and de Koch, M. J. D. 2006. Cyclic lipopeptide production by plant-associated Pseudomonas spp.: Diversity, activity, biosynthesis and regulation. Mol. Plant-Microbe Interact. 19:699-710.

Rainey, P. B. 1999. Adaptation of Pseudomonas fluorescens to the plant rhizosphere. Environ. Microbiol. 3:243-257.

Ramette, A., Frapolli, M., Saux, M. F. L., Gruffaz, C., Meyer, J. M., Défago, G., Sutra, L., and Moënne-Loccoz, Y. 2011. Pseudomonas protegens $\mathrm{sp}$ nov., widespread plant-protecting bacteria producing the biocontrol compounds 2,4-diacetylphloroglucinol and pyoluteorin. Syst. Appl. Microbiol. 34:180-188.

Rochat, L., Péchy-Tarr, M., Baehler, E., Maurhofer, M., and Keel, C. 2010. Combination of fluorescent reporters for simultaneous monitoring of root colonization and antifungal gene expression by a biocontrol pseudomonad on cereals with flow cytometry. Mol. Plant-Microbe Interact. 23:949-961.

Saitou, N., and Nei, M. 1987. The neighbor-joining method: A new method for reconstructing phylogenetic trees. Mol. Biol. Evol. 4:406425.

Sambrook, J., and Russell, D. W. 2001. Molecular Cloning: A Laboratory Manual, third ed. Cold Spring Harbor Laboratory, Cold Spring Harbor, NY, U.S.A.

Sambrook, J., Fritsch, E. F., and Maniatis, T. 1989. Molecular Cloning: A Laboratory Manual, second ed. Cold Spring Harbor Laboratory, Cold Spring Harbor, NY, U.S.A

Sokal, R. R., and Rohlf, F. J. 1986. Introducción a la bioestadística. S. A Reverté, ed. Barcelona, Spain.

Sztejnberg, A., and Madar, Z. 1980. Host range of Dematophora necatrix, the cause of white root rot disease in fruit trees. Plant Dis. 64:662 664.

Tamura, K., Peterson, D., Peterson, N., Stecher, G., Nei, M., and Kumar, S. 2011. MEGA5: Molecular evolutionary genetics analysis using maximum likelihood, evolutionary distance, and maximum parsimony methods. Mol Biol. Evol. $28.2731-2739$. 
Thomashow, L. S., and Weller, D. M. 1988. Role of phenazine antibiotic from Pseudomonas fluorescens in biological control of Gaeumannomyces graminis var. tritici. J. Bacteriol. 170:3499-3508.

Thomashow, L. S., Bonsall, R. F., and Weller, D. M. 1997. Antibiotic production by soil and rhizosphere microbes in situ. Pages 493-499 in: Manual of Environmental Microbiology. C. J. Hurst, G. R. Knudsen, M. J. Mclnerney, L. D. Stetzerbach, and M. V. Walter, eds. American Society for Microbiology, Washington, DC.

Vanden Boom, T. J., Reed, K. E., and Cronan, J. E., Jr. 1991. Lipoic acid metabolism in Escherichia coli: Isolation of null mutants defective in lipoic acid biosynthesis, molecular cloning and characterization of the E. coli lip locus, and identification of the lipoylated protein of the glycine cleavage system. J. Bacteriol. 173:6411-6420.

Vazquez, A., Markert, E. K., and Oltvai, Z. N. 2011. Serine biosynthesis with one carbon catabolism and the glycine cleavage system represents a novel pathway for ATP generation. PLoS ONE 6:e25881. Published online.

Vincent, M. N., Harrison, L. A., Brackin, J. M., Kovacevich, P. A., Murkerji, P., Weller, D. M., and Pierson, E. A. 1991. Genetic analysis of the anti- fungal activity of a soilborne Pseudomonas aureofaciens strain. Appl. Environ. Microbiol. 57:2928-2934.

Weller, D. 2007. Pseudomonas biocontrol agents of soilborne pathogens: Looking back over 30 years. Phytopathology 97:250-256.

Whistler, C. A., Stockwell, V. O., and Loper, J. E. 2000. Lon protease influences antibiotic production and UV tolerance of Pseudomonas fluorescens Pf-5. Appl. Environ. Microbiol. 66:2718-2725.

Winsor, G. L., Lam, D. K., Fleming, L., Lo, R., Whiteside, M. D., Yu, N. Y., Hancock, R. E., and Brinkman, F. S. 2011. Pseudomonas Genome Database: Improved comparative analysis and population genomics capability for Pseudomonas genomes. Nucleic Acids Res. 39:D596D600.

\section{AUTHOR-RECOMMENDED INTERNET RESOURCES}

European Molecular Biology Laboratory-European Bioinformatics Institute: www.ebi.ac.uk

JustBio website: www.justbio.com 